\title{
Entomofauna associated with Avena sativa in southern Mato Grosso do Sul, Brazil
}

\author{
Entomofauna associada à cultura da aveia \\ branca no sul do Mato Grosso do Sul, Brasil
}

\author{
Rafael Azevedo da Silva1* (D), Paulo Degrande ${ }^{2}$ (D), Ellen Patricia de Souza² (D), \\ Carlos Eduardo Carducci ${ }^{2}$ (D), Matheus Fuchs Leal ${ }^{2}$ (D), Matheus Dalla Cort Pereira ${ }^{2}$
}

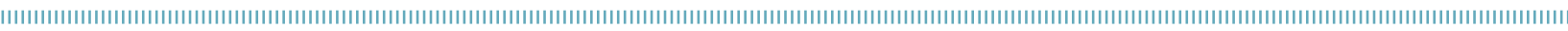

\begin{abstract}
This study was aimed at examining the composition of insects and fluctuations in their populations in Avena sativa in southern Mato Grosso do Sul. The study was carried out at the experimental farm of the Federal University of Grande Dourados (FAECA) in Dourados, Mato Grosso do Sul, in 2014 and 2015, in an area of three hectares divided into 80 plots of $169 \mathrm{~m}^{2}$ each. The assessments were carried out weekly by sampling the area within a $0.25-\mathrm{m}^{2}$ metal frame, totaling ten evaluations. Within the frame, ten plants were examined for aphids and all plants were inspected for other insects. Based on the faunistic analysis (abundance, constancy, frequency, and dominance), eight species were observed during the two years of study. The most frequent, abundant, dominant, and recurring species were Rhopalosiphum padi, Spodoptera frugiperda and dipterans of the family Syrphidae (hoverfly). The population of $R$. padi increased until approximately the 40th day after emergence (DAE), when the highest abundance of hoverflies was also observed. After that, the population of $R$. padi decreased. The aphid $R$. padi was the main insect observed in $A$. sativa during the two years of study but were naturally controlled by hoverflies; therefore, chemical intervention was not needed.
\end{abstract}

KEYWORDS: aphids; diversity; Rhopalosiphum padi; Shyrphidae.
RESUMO: O objetivo deste trabalho foi analisar a composição faunística de insetos e sua flutuação populacional em Avena sativa na regiāo sul do Mato Grosso do Sul. O experimento foi conduzido na Fazenda Experimental da Universidade Federal de Grande Dourados (FAECA), em Dourados, Mato Grosso do Sul, em uma área de três hectares divididos em 80 lotes de $169 \mathrm{~m}^{2}$ cada, nos anos de 2014 e 2015. As avaliações foram realizadas semanalmente por amostragem da área em uma estrutura metálica de $0,25 \mathrm{~m}^{2}$, perfazendo um total de dez avaliaçóes. Dentro da estrutura, dez plantas foram examinadas para pulgóes e todas as plantas foram inspecionadas quanto a outros insetos. Baseado na análise faunística (abundância, constância, frequência e dominância), oito espécies foram observadas durante os dois anos de estudo. As espécies mais frequentes, abundantes, dominantes e constantes foram Rhopalosiphum padi, Spodoptera frugiperda e dípteros da família Syrphidae. A população de $R$. padi aumentou até aproximadamente o $40^{\circ}$ dia após a emergência (DAE), momento esse em que também houve a maior presença de sirfídeos. A partir deste ponto, ocorreu a diminuição na populaçáa de $R$. padi. O pulgáo $R$. padi foi o principal inseto observado em $A$. sativa durante os dois anos de estudo, mas paralelamente houve um bom controle natural por sirfídeos, sendo dispensável, portanto, a necessidade de intervenções químicas.

PALAVRAS-CHAVE: afídeos; diversidade; Rhopalosiphum padi; Shyrphidae. 


\section{INTRODUCTION}

The oat (Avena sativa $\mathrm{L}$.) is a multipurpose cereal that can be used for consumption by humans as grain or by animals as forage, hay, pasture, or silage, as well as for ground coverage for no-till systems (DAL MOLIN, 2011; CASTRO et al., 2012).

In recent years, this cash crop has become an important alternative during Winter, especially in southern Brazil. Therefore, more productive plants of high quality are needed in response to the improvement of environmental stimuli (SILVA et al., 2012; HAWERROTH et al., 2013).

Currenty, $10 \%$ of the oats produced in Brazil are grown in the state of Mato Grosso do Sul. However, the cultivated area is likely to increase, as $A$. sativa is an alternative to corn in crop rotation and succession systems in the Fall/Winter (RICHETTI; CECCON, 2008; CONAB, 2019).

The Dourados region has the potential to grow oats, as this crop has low water requirements, wide tolerance to soil $\mathrm{pH}$ (4.5 to 8.5), and resistance to the frosts that occur in autumn and Winter in this area. In addition, large quantities of straw are produced, representing a better use of the soil, decreasing erosion, while weed growth is inhibited by the allelopathic effects of oats (CASTRO et al., 2012). On the other hand, some factors may negatively affect yields, especially pests such as the aphid Rhopalosiphum padi (Linnaeus, 1758) (Hemiptera: Aphididae) and the caterpillar of Spodoptera frugiperda (Smith, 1797) (Lepidoptera: Noctuidae), which has a high incidence in oats in traditional growing areas. The effect of the attack of $R$. padi can be also be exacerbated by the transmission of viruses such as the barley yellow dwarf virus (BYDV) in Winter cereals (ROZA-GOMES et al., 2008).

Given the few scientific studies on pests of oats, most of the information on pest management has been generally based on other similar crops, such as wheat (ROZA-GOMES et al., 2008; PEREIRA; SALVADORI, 2011; PANIZZI et al., 2015). Therefore, information is needed on the diversity of insect species associated with oats in order provide a framework for pest control based on Integrated Pest Management (IPM) (GALLO et al., 2002).

This study was aimed at assessing the entomofauna and fluctuations in their populations in oats in Dourados, Mato Grosso do Sul, Brazil.

\section{MATERIALS AND METHODS}

The study was conducted at the Experimental Farm of Agricultural Sciences (FAECA) of the Federal University of Grande Dourados (UFGD), Dourados (22 23 S, $54^{\circ} 98 \mathrm{~W}$ ), Mato Grosso do Sul, Brazil, in the 2014 and 2015 harvests, in an area of three hectares planted with oats.
In 2014, pre-planting desiccation was carried out on April $11^{\text {th }}$ with the herbicides glyphosate (480 SL) and 2,4-D + amine (720 SL) at the doses of three and one L/ha, respectively. Sowing occurred on April $28^{\text {th }}$, at a density of 80 seeds per linear meter and basic fertilizing of N-P-K of $400 \mathrm{~kg} / \mathrm{ha}$ of 8-20-20.

The pesticides used during oat growth were picoxystrobin $(200$ SC) + cyproconazole (80 SC) at a dose of $0.3 \mathrm{~L} / \mathrm{ha}$ on July $10^{\text {th }}$ and trifloxystrobin $(150 \mathrm{SC})+$ protioconazole (175 SC) $0.4 \mathrm{~L} /$ ha on July $25^{\text {th }}$. No post-emergence insecticides and herbicides were used.

In the 2015 harvest, pre-planting desiccation was carried out on April $24^{\text {th }}$ with the herbicides glyphosate ( $480 \mathrm{SL}$ ) and 2,4-D + amine (720 SL) in the dosages of four and one L/ha, respectively. Sowing was performed on May $18^{\text {th }}$, at a density of 80 seeds per linear meter and basic fertilization of N-P-K of $400 \mathrm{~kg} / \mathrm{ha}$ of $8-20-20$.

The crop practices used consisted of propiconazole $(250 \mathrm{EC})$ + diphenoconazole (250 EC) applications at a dosage of 0.150 L/ha on June $22^{\text {nd }}$, picoxystrobin (200 SC) + cyproconazole $(80 \mathrm{SC})$ at a dose of $0.3 \mathrm{~L} / \mathrm{ha}$ on July $15^{\text {th }}$, and trifloxystrobin $(150 \mathrm{SC})+$ protioconazole $(175 \mathrm{SC}) 0.4 \mathrm{~L} / \mathrm{ha}$ on July $31^{\text {st }}$. No post-emergence insecticides and herbicides were used.

The cultivated area used for the study was $13,520 \mathrm{~m}^{2}$, subdivided into 80 plots of $169 \mathrm{~m}^{2}$ each. In 2014, the first assessment was carried out at 12 days after emergency (DAE), followed by weekly evaluations, totaling 10 assessments in the year. In 2015, the first assessment was performed at $10 \mathrm{DAE}$, with nine evaluations.

Twenty insects were sampled in the field and identified at species level in the laboratory with the aid of identification keys (GALLO et al., 2002; PEREIRA; SALVADORI, 2011).

For each sampling point, a $0.5 \times 0.5\left(0.25 \mathrm{~m}^{2}\right)$ metal frame was used, and the number of insects found within the area delimited by the frame was counted. One sampling point was examined per plot. Aphids were examined by removing ten plants within the frame and counting the insects found in their aerial and root parts. For the other species, direct counting of insects presents in the plants and on the soil, and surface was carried out within the area delimited by the frame.

The entomofauna was analyzed using the ANAFAU software (MORAES et al., 2003). Following SILVEIRA NETO et al. (1995), the species with the highest indices, based on abundance, constancy, dominance, and frequency, were considered predominant.

Abundance was determined using the mean and standard error of the mean number of individuals sampled per species, thus determining a confidence interval (CI) at 5 and $1 \%$ probability and establishing the following abundance classes: $\mathrm{sa}=$ superabundant (discrepant values of insect number, identified by the residue analysis); va = very abundant (number of individuals greater than the upper limit of $1 \% \mathrm{CI}$ ); $\mathrm{a}=\mathrm{abun}$ dant (number of individuals within the upper limits of the 
$\mathrm{CI}$ at 5 and $1 \%$ ); $\mathrm{c}=$ common (number of individuals within $5 \% \mathrm{CI}$ ); $\mathrm{d}=$ dispersed (number of individuals between the lower limit of $\mathrm{CI}$ at 5 and $1 \%$ ); and $\mathrm{r}=$ rare (number of individuals lower than the lower limit of $\mathrm{CI}$ at $1 \%$ ) (THOMAZINI; THOMAZINI, 2002; MORAES et al., 2003).

The confidence interval of the mean frequency (percentage of individuals of a species in relation to the total number of individuals sampled) was determined with a probability of 5\%, and the following classification was adopted: $\mathrm{sf}=$ super frequent (discrepant values of the number of insects, identified with the residue analysis); $\mathrm{vf}=$ very common (frequency greater than the upper limit of $5 \% \mathrm{CI}$ ); $\mathrm{f}=$ frequent (frequency within $5 \% \mathrm{CI}$ ); and If $=$ uncommon (frequency lower than the lower limit of $5 \% \mathrm{CI}$ ) (THOMAZINI; THOMAZINI, 2002; MORAES et al., 2003).

Constancy was determined for each species by assessing the percentage of samples with a given species, calculated as follows: $\mathrm{C}=$ (number of species $\mathrm{x} /$ total number of samples) $\times 100$. According to the values obtained, species were grouped into $\mathrm{w}=$ constant $(\mathrm{C}>50 \%) ; \mathrm{y}=$ accessory $(\mathrm{C}$ between 25 and $50 \%)$; and $\mathrm{z}=$ incidental $(\mathrm{C}<25 \%)$. Species with frequencies exceeding the limit calculated by the formula were considered dominant: $\mathrm{D}=1$ /total number of species $\times 100$ (THOMAZINI; THOMAZINI, 2002).

The relationship between the population of $R$. padi and syrphids was examined with the chi-square test $\left(\mathrm{x}^{2}\right)$, which compares observed and expected frequencies (RODRIGUES et al., 2010).

Temperature and rainfall data were obtained from the weather station of the Experimental Farm of Agricultural Sciences (FAECA) of the Federal University of Grande Dourados (UFGD).

\section{RESULTS AND DISCUSSION}

During the sampling period, eight species divided into four orders and six families were collected in 2014, totaling 26,262 specimens (Table 1). In 2015, eight species representing four orders, seven families and 5,099 specimens were sampled (Table 2).

Table 1. Number of collected specimens, number of assessments and analysis of the insects associated to Avena sativa. Groups by order, family, and species in 2014. Dourados, Mato Grosso do Sul, 2017.

\begin{tabular}{lccccccccc} 
Order/family & Species & Stage* & N ind. & N assess. & Dom** & Abu** & Freq** & Const** \\
Hemiptera: Aphididae & Rhopalosiphum padi & Ad & 22.984 & 10 & SD & SA & SF & W \\
\hline Hemiptera: Aphididae & Schizaphis graminum & Ad & 1.462 & 7 & D & VA & VF & W \\
\hline Lepidoptera: Noctuidae & Spodoptera frugiperda & Cat & 1.183 & 10 & D & A & VF & W \\
\hline Lepidoptera: Noctuidae & Mocis latipes & Cat & 746 & 9 & D & A & VF & W \\
\hline Coleoptera: Chrysomelidae & Diabrotica speciosa & Ad & 108 & 9 & D & C & F & W \\
\hline Coleoptera: Coccinelidae & Harmonia axyridis & Ad + L & 63 & 2 & D & C & F & Z \\
\hline Coleoptera: Tenebrionidae & Lagria villosa & Ad & 55 & 9 & D & C & F & W \\
\hline Diptera: Shyrphidae & Syrphids & L & 407 & 6 & D & C & F & W \\
\hline *Catcaterp & & & & & & &
\end{tabular}

*cat: caterpillar; I: larva; ad: adult.

**Dominance: SD - superdominant, D - dominant; A - abundance: SA - superabundant, VA - very abundant, A - abundant, C - common;

Frequency: SF - super frequent, VF - very frequent, $F$ - frequent; (C) Constance: (W) constant, ( $\mathrm{Z}$ ) incidental.

Table 2. Number of collected specimens, number of assessments and analysis of the insects associated to Avena sativa. Groups by order, family, and species in 2015. Dourados, Mato Grosso do Sul, 2017.

\begin{tabular}{lcccccccc} 
Order/family & Species & Stage* & N ind. & N assess. & Dom** & Abu** & Freq** & Const** \\
Hemiptera: Aphididae & Rhopalosiphum padi & Ad & 4.726 & 9 & SD & SA & SF & W \\
\hline Hemiptera: Reduvidae & Zelus longipes & Ad + N & 9 & 1 & D & R & PF & Z \\
\hline Lepidoptera: Noctuidae & Spodoptera frugiperda & Cat & 118 & 8 & D & VA & VF & W \\
\hline Lepidoptera: Noctuidae & Mocis latipes & Cat & 78 & 6 & D & C & F & W \\
\hline Coleoptera: Chrysomelidae & Diabrotica speciosa & Ad & 28 & 9 & D & C & F & W \\
\hline Coleoptera: Coccinelidae & Harmonia axyridis & Ad + L & 23 & 8 & D & C & F & Z \\
\hline Coleoptera: Tenebrionidae & Lagria villosa & Ad & 68 & 8 & D & C & F & W \\
\hline Diptera: Shyrphidae & Syrphids & L & 130 & 9 & D & VA & VF & W \\
\hline
\end{tabular}

*cat: caterpillar; I: larva; ad: adult.

**Dominance: SD - superdominant, D - dominant; A - abundance: SA - superabundant, VA - very abundant, A - abundant, C - common;

Frequency: SF - super frequent, VF - very frequent, F - frequent; (C) Constance: (W) constant, (Z) incidental. 
In 2014, the order Hemiptera had the highest indices, with Rhopalosiphum padi and Schizaphis as dominant and constant species. In 2015 , $R$. padi was superdominant, superabundant, super frequent, and constant.

Aphids were the main pest insects attacking oats in the present study, especially $R$. padi, thus confirming its status as the most important pest in cereals worldwide, and among the most important aphids in agriculture (LOECK et al., 2006; BLACKMAN; EASTOP, 2007).

Our results are in accordance with those by LAU et al. (2009), that reported $R$. padi and S. graminum as the main aphids found in wheat and oats Southern Brazil and the state Mato Grosso do Sul. According to these authors, $R$. padi has adapted well to Brazilian conditions, increasing the risk of transmission of the barley (BYDV)/cereal yellow dwarf viruses (CYDV) to which this insect is a vector.

PARIZOTO et al. (2013) studying the main vector insects of the BYDV virus, identified $R$. padi and $S$. graminum as main pests, representing 68.6 and $15 \%$, respectively, of the total aphids sampled in wheat and oats.

In addition, the temperature during this study was ideal for $R$. padi, resulting in its highest reproduction and development rates, as shown in (Fig. 1), which was around 18.9 and $19.5^{\circ} \mathrm{C}$ in 2014 and 2015 respectively (AUAD et al., 2009; PEREIRA et al., 2016).

The order Lepidoptera was as one of the most abundant with 1,929 individuals in 2014, represented by the species Spodoptera frugiperda and Mocis latipes, while in 2015 these same species accounted for 196 specimens. Larvae of $S$. frugiperda and $M$. latipes were the predominant species, very frequent and constant in the first year of study. In the second year, $S$. frugiperda remained dominant, very abundant, and frequent, however the population of $M$. latipes decreased, becoming a common and frequent species.

One of the major factors affecting the dynamics of S. frugiperda in the environment is the high availability of
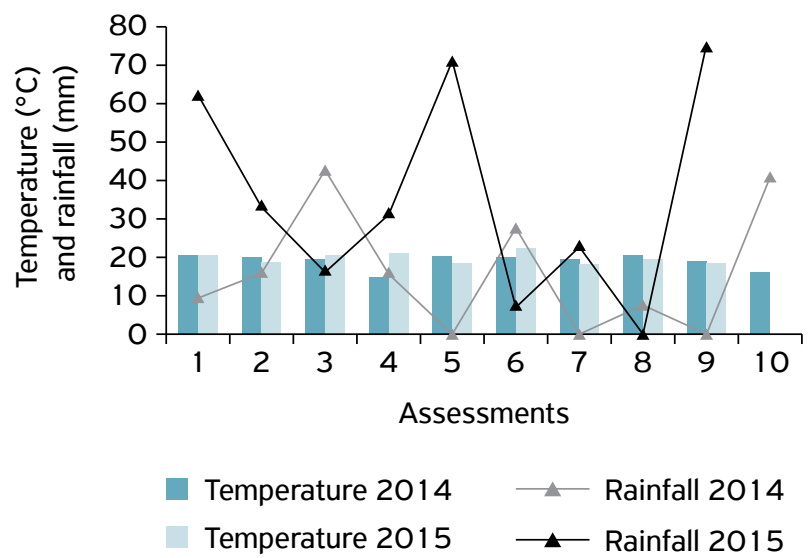

Figure 1. Climate parameters during the periods of evaluation in Avena sativa in 2014 and 2015 in the municipality of Dourados, Mato Grosso do Sul. food, including invasive and cultivated plants (GALLO et al., 2002). Therefore, polyphagia in $S$. frugiperda may be reflected in its higher indices in oats in this study. Despite that, not all plants equally used, with species of the Poaceae family as the preferred hosts of this pest in America (SÁ et al., 2009; CASMUZ et al., 2010).

The insects of the family Shyrphidae accounted for 407 specimens in 2014 and 130 in 2015 . They were considered dominant, frequent, and constant in this study. In addition, an interaction between the syrphid population and $R$. padi (Fig. 2) was observed, where in the years of study the largest syrphid populations occurred close to the largest $R$. padi populations. Table 3 shows the results of the chi-square test indicating the association of the abundance of these species, based on the p-value below the significance level of 0.05 . In addition, when abundance of syrphids was high, oat plants were flowering, thus providing food for adults of this insect.

The presence of aphidophagous syrphids is determined by climatic factors, availability of flowers and preys, habitat, and geographical area, which is positively correlated with aphid population (AUAD; TREVIZANI, 2005; BOKINA, 2012). Moreover, the ability of these insects to oviposite near aphid colonies and their voracity make them effective aphid predators (ALMOHAMAD et al., 2009).

According to BOKINA (2012), the main factor affecting the abundance of syrphids in cereals is the density of aphid population, and in crop rotation system, these insects prefer plants with the highest aphid reproduction rates. This author,
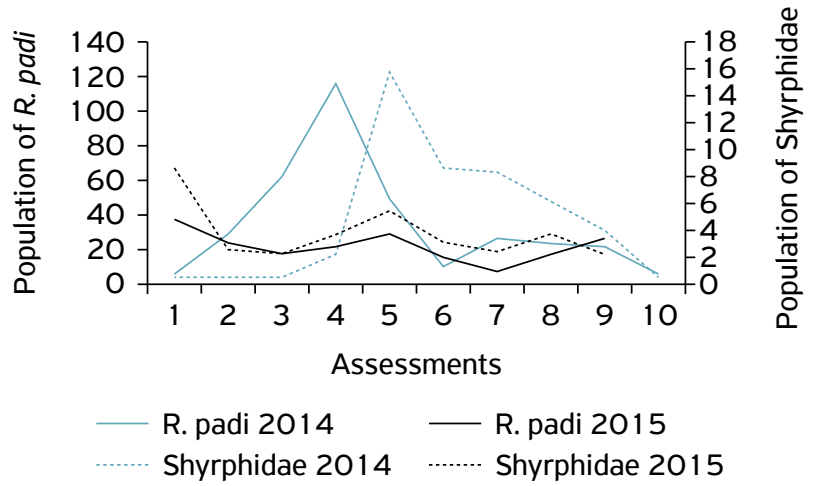

Figure 2. Population fluctuation of Rhopalosiphum padi and Syrphids during the assessments in 2014 and 2015 in Dourados, Mato Grosso do Sul.

Table 3. Chi-square test of adherence between Rhopalosiphum padi and Sirphids in the years 2014 and 2015 in Avena sativa in Dourados, Mato Grosso do Sul, 2017.

\begin{tabular}{lccc} 
Year of survey & Chi-square test & GF & p-value \\
\hline 2014 & $3778.1^{*}$ & 18 & $2.2 \mathrm{e}-16$ \\
\hline 2015 & $1015.2^{*}$ & 18 & $2.2 \mathrm{e}-16$ \\
\hline
\end{tabular}

*Significant at $5 \%$ according to the chi-square test. 
studying the aphid population in cereals, also found that the largest populations of $R$. padi occurred in oats, concomitant with the largest syphid populations.

Coleoptera accounted for 570 insects, represented by the species Diabrotica speciosa, Lagria villosa, and Harmonia axyridis in 2014 and 2015. The species L. villosa, D. speciosa, and $H$. axyridis were considered dominant, common, and frequent, respectively, in the two years of study. $H$. axyridis, in 2014, was considered an incidental species.

Comparatively, the predator $H$. axyridis was less abundant than syrphids, but it also is an important biological aphid control agent and has a positive correlation with the population of this pest $(\mathrm{KOCH}, 2003)$.

In this study, diversity, richness, and abundance revealed a community composed of a small number of abundant species, acceptable in monocultures (SILVEIRA NETO et al.,
1995). Since this crop is relatively recent in the region, this might reflect a pest-insect complex less adapted to this crop.

Our findings indicate which pest and beneficial insects occur in Southern Mato Grosso do Sul in oats. This information provides a framework for studies on Integrated Pest Management, ecology, and taxonomy, as a scientific basis for those involved in the production chain of this grain.

\section{CONCLUSIONS}

The entomofauna associated to oat crops was not diversified during the years this study.

The main pest insect associated to Avena sativa is $R$. padi. Syrphids are the most abundant insects along with $R$. padi.

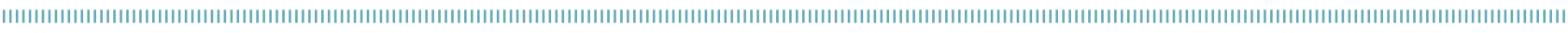
REFERENCES

ALMOHAMAD, R.; VERHEGGEN, F.J.; HAUBRUGE, É. Searching and oviposition behavior of aphidophagous hoverflies (Diptera: Syrphidae): a review. Biotechnologie, Agronomie, Société et Environnement, v.13, n.3, p.1-11, 2009.

AUAD, A.M.; TREVIZANI, R. Ocorrência de sirfídeos afidófagos (Diptera: Syrphidae) em Lavras, MG. Revista Brasileira de Entomologia, v.49, 3, p.425-426, 2005.

AUAD, A.M.; ALVES, S.O.; CARVALHO, C.A.; SILVA, D.M.; RESENDE, T.T.; VERÍSSIMO, B.A. The impact of temperature on biological aspects and life table of Rhopalosiphum padi (Hemiptera: Aphididae) fed with signal grass. Florida Entomologist, v.92, n.4, p.569-577, 2009. https://doi.org/10.1653/024.092.0406

BLACKMAN, R.; EASTOP, V. Taxonomic issues. In: VAN EMDEN, H.F.; HARRINGTON, R. (Eds.). Aphids as Crop Pests. Oxfordshire: CABI Publishing, 2007. p.1-29.

BOKINA, I.G. Hoverflies (Diptera, Syrphidae) in agrocenoses of the forest steppe of Western Siberia and the influence of agrotechnological practice on their abundance. Entomological Review, v.92, n.9, p.10531060, 2012. https://doi.org/10.1134/SO0 $1387381209014 \mathrm{X}$

CASMUZ, A.; JUÁREZ, M.L.; SOCÍAS, M.G.; MURÚA, M.G.; PRIETO, S.; MEDINA, S.; GASTAMINZA, G. Review of the host plants of fall armyworm, Spodoptera frugiperda (Lepidoptera: Noctuidae). Revista de la Sociedad Entomológica Argentina, v.69, n.3-4, p.209-231, 2010.

CASTRO, G.S.A.; COSTA, C.H.M.; FERRARI NETO, J. Ecofisiologia da aveia branca. Scientia Agraria Paranaensis, v. 1 1, n.3, p. 1-15, 2012. http://dx.doi.org/10.1818/sap.v1 1 i3.4808

COMPANIA NACIONAL DE ABASTECIMENTO (CONAB). Acompanhamento da safra brasileira: grãos, sétimo levantamento. Safra 2018/2019. Brasília: CONAB, 2019. v.6. p.98. Available from: <https://www.conab.gov.br/info-agro/safras/graos/boletimda-safra-de-graos>. Access on: May 202019.
DAL MOLIN, V.T.S. Avaliação Química e Sensorial do Grão da Aveia em diferentes formas de Processamento. 2011 . 80f. Dissertação (Mestrado em Agronomia) - Universidade Federal de Santa Maria Santa Maria, 2011.

GALLO, D.; NAKANO, O.; SILVEIRA NETO, S.; CARVALHO, R.P.L.; BAPTISTA, G.C.V.; BERTI FILHO, E.; PARRA, J.R.P.; ZUCCHI, R.A.; ALVES, S.B.; VENDRAMIM, J.D.X.; MARCHINI, L.C.; LOPES, J.R.S.; OMOTO, C. (Eds.). Entomologia agrícola. Piracicaba: FEALQ, 2002. 920p.

HAWERROTH, M.C.; CARVALHO, F.I.F.; OLIVEIRA, A.C.; SILVA, J.A.G.; GUTKOSKI, L.C.; SARTORI, J.F.; WOYANN, L.G.; BARBIERI, R.L.; HAWERROTH, F.J. Adaptability and stability of white oat cultivars as to chemical composition of the caryopsis. Pesquisa Agropecuária Brasileira, v.48, n. 1, p.42-50, 2013. http://dx.doi. org/10.1590/SO100-204X2013000100006

KOCH, R.L. The multicolored Asian lady beetle, Harmonia axyridis: a review of its biology, uses in biological control, and non-target impacts. Journal of Insect Science, v.3, p.1-16, 2003. https:// doi.org/10.1093/jis/3.1.32

LAU, D.; PEREIRA, P.D.S.; SALVADORI, J.R.; SCHONS, J.; PARIZOTO, G.; MAR, T.B. Ocorrência do Barley/Cereal yellow dwarf virus e seus vetores em cereais de inverno no Rio Grande do Sul, Santa Catarina, Paraná e Mato Grosso do Sul em 2008. Passo Fundo: Embrapa Trigo, 2009. Comunicado Técnico (INFOTECA-E). Available from: <https://www.infoteca. cnptia.embrapa.br/bitstream/doc/822137/1/pco256.pdf >. Access on: Oct. 202017.

LOECK, A.E.; GIOLO, F.P.; MANZONI, C.G.; DA SILVA BORBA, R.; DE AZEVEDO, R.; CENTENARO, E.D. Reprodução dos pulgões Rhopalosiphum padi (Linnaeus, 1758) e Schizaphis graminum (Rondani, 1852) (Hemiptera: Aphididae) em cultivares de aveia branca. Revista Brasileira de Agrociência, v. 12, n.2, p.237-240, 2006. http://dx.doi.org/10.18539/cast.V1212.4543 
MORAES, R.C.B.; HADDAD, M.D.L.; SILVEIRA NETO, S.; REYES, A.E.L. Software para análise faunística - ANAFAU. In: SIMPÓSIO DE CONTROLE BIOLÓGICO, 8., São Pedro, SP. Resumos... Piracicaba: ESALQ/USP, 2003. p. 195.

PANIZZI, A.R.; AGOSTINETTO, A.; LUCINI, T.; SMANIOTTO, L.F.; PEREIRA, P.R.V.S. Manejo integrado dos percevejos barriga-verde, Dichelops spp. em trigo. Passo Fundo: Embrapa Trigo, 2015. (Ser. Documentos, v.114).

PARIZOTO, G.; REBONATTO, A.; SCHONS, J.; LAU, D. Barley yellow dwarf virus-PAV in Brazil: seasonal fluctuation and biological characteristics. Tropical Plant Pathology, v.38, n. 1, p.11-19, 2013. http://dx.doi.org/10.1590/S1982-56762013000100002

PEREIRA, P.R.V.S.; SALVADORI, J.R. Pragas da lavoura de trigo. In: PIRES, J.L.F.; VARGAS, L.; CUNHA, G.R. (Eds.). Trigo no Brasil. Passo Fundo: Embrapa Trigo, 2011.p.263-282.

PEREIRA, P.R.V.S.; DOSSA, C.C.K.; DOSSA, A.A.; LAU, D. Longevidade e prolificidade de Rhopalosiphum padi (L.)(Hemiptera: Aphididae) em duas cultivares de trigo sob diferentes temperaturas. Passo Fundo: Embrapa Trigo, 2016. 7p. (Circular Técnica, 366). Available from: <https://www.infoteca.cnptia.embrapa.br/infoteca/bitstream/ doc/1061491/1/ID438872016CT0366.pdf>. Access on: Oct. 202017.

RICHETTI, A.; CECCON, G. Estimativa do custo de produção de Aveia Branca para a Região de Dourados, MS, 2008. Dourados: Embrapa Agropecuária Oeste, 2008. (Comunicado Técnico, 143). Available from: <https://www.infoteca.cnptia.embrapa. br/infoteca/handle/doc/255735>. Access on: May 202019.
RODRIGUES, T.R.; FERNANDES, M.G.; SANTOS, H.R. Spatial distribution of Aphis gossypii (Glover) (Hemiptera, Aphididae) and Bemisia tabaci (Gennadius) biotype B (Hemiptera, Aleyrodidae) on Bt and non-Bt cotton. Revista Brasileira de Entomologia, v.54, n.1, p.136-143, 2010. http://dx.doi.org/10.1590/S0085-56262010000100019

ROZA-GOMES, M.F.; SALVADORI, J.R.; SCHONS, J. Danos de Rhopalosiphum padi (L.) (Hemiptera: Aphididae) no trigo em função da duração e da densidade de infestação. Neotropical Entomology, v.37, n.5, p.577-581, 2008. http://dx.doi. org/10.1590/S1519-566X2008000500013

SÁ, V.; FONSECA, B.V.; BOREGAS, K.G.; WAQUIL, J.M. Sobrevivência e desenvolvimento larval de Spodoptera frugiperda (JE Smith) (Lepidoptera: Noctuidae) em hospedeiros alternativos. Neotropical Entomology, v.38, n.1, p.108-115, 2009. http://dx.doi. org/10.1590/S1519-566X2009000100012

SILVA, J.A.G.; FONTANIVA, C.; COSTA, J.S.P.; KRÜGER, C.A.M.B.; UBESSI, C.; PINTO, F.B.; ARENHARDT, E.G.; GEWEHR, E. Uma proposta na densidade de semeadura de um biótipo atual de cultivares de aveia. Revista Brasileira de Agrociência, v. 18, n.4, p.253-263, 2012.

SILVEIRA NETO, S.S.; MONTEIRO, R.C.; ZUCCHI, R.A.; MORAES, R.C.B. Uso da análise faunística de insetos na avaliação do impacto ambiental. Scientia Agrícola, v.52, n.01 p.09-15, 1995. http:// dx.doi.org/10.1590/SO103-90161995000100003

THOMAZINI, M.J.; THOMAZINI, A.P. Bee diversity (Hymenoptera: Apoidea) in inflorescences of Piper hispidinervum (C. DC.). Neotropical Entomology, v.31, n. 1, p.27-34, 2002. http:// dx.doi.org/10.1590/S1519-566X2002000100004 